\title{
Autobiografia e liderança indígena no Brasil
}

\author{
Oscar Calavia Sáez
}

Resumo: A autobiografia é um tema quase inédito na etnologia indígena brasileira. As idéias sobre os índios no Brasil, seja no âmbito acadêmico seja no domínio jurídico seja no imaginário popular, excluem as formas individuais: os sujeitos indígenas devem ser coletivos. Mas o movimento indígena brasileiro está presenciando, há anos, a aparição de novos líderes que estabelecem novas alianças políticas e novos modos de legitimação, e que vão incluindo a primeira pessoa do singular nos seus discursos, feitos predominantemente em nome de um coletivo. Esses líderes começaram também a escrever ou a ditar memórias pessoais, e mesmo autobiografias propriamente ditas. Neste artigo, apresentarei quatro exemplos muito diferentes desta tendência: as narrações de um líder Yaminawa, de um xamã e porta-voz Yanomami, de um professor, ator e ex-cacique Guarani e de um sacerdote católico Tuyuka. Além de questões óbvias como a origem étnica de cada narrador, o tamanho ou a estrutura dos relatos ou o modo em que eles foram colhidos, argumentarei que a principal diferença entre eles está no modo em que o sujeito autobiográfico se situa no cenário local e global. Cada narração retrata seu autor como índio, e o faz de modos diferentes, devido às diversas relações entre indios e brancos que definem esses termos em cada caso.

Palavras-chave: autobiografia; liderança indígena; tradução.

Abstract: The autobiography is an almost unprecedented theme in Brazilian indigenous ethnology. Ideas about Brazilian Indians, whether in academic circles or in the juridical dominion or yet in the popular imagination, exclude the individual forms: Indian subjects should be collective. But the Brazilian indigenous movement has been witnessing, for years, the appearance of new leaders who establish new political alliances and new ways of making things legitimate, and who include the first person singular in their discourse, given mainly in the collective name. These leaders began also to write or to dictate personal memories, and even actual biographies. In this article, I shall present four very different examples of this tendency: the narrations of a Yaminawa leader, of a Yanomami shaman and spokesman, of a Guarani teacher, actor and ex-Indian chief and of a Tuyuka catholic priest. As well as obvious questions like the ethnic origin of each narrator, the size and structure of the reports or the way in which they were collected, I shall argue that the main difference between them is in the way in which the autobiographical

Professor do Departamento de Antropologia da Universidade Federal de Santa Catarina. Doutor em Antropologia pela Universidade de São Paulo. PósDoutorado pela EREACNRS, Paris. occs@uol.com.br http://www.cfh.ufsc.br/ oscar/

Tellus, ano 7, n. 12, p. 11-32, abr. 2007

Campo Grande - MS 
subject situates himself on the local and global scene. Each narrative reflects its author as an Indian, and does it in different ways, because of the diverse relationships between Indians and whites which define these terms in each case.

Key words: autobiography; indigenous leadership; translation.

Este artigo trata de relatos em que protagonista e autor se dão a conhecer como uma mesma pessoa. Mas começará com um resumo em estilo indireto de uma longa fala cujo autor permanecerá anônimo:

Começou a ser liderança aos dezenove anos. Foi um presente da comunidade, porque era o único sobrevivente de sua família, ou de quatro irmãos dos que só ele restou. Ficou louco, queria acabar, se perder, ir morar entre os brancos. Foi por isso que ganhou o presente. Aí foi, de fato. Mais tarde voltou para liderar lá dentro. Deram-lhe uma mulher que tinha trinta anos a mais do que ele, essa era a lei. Podia ser sua avó e ele não quis, raptou outra mulher (não a atual, outra). A liderança tem a ver com o exterior, serve sobretudo para explicar aos índios as coisas de fora, para que entendam as coisas dos brancos. Os Yaminawa tiveram muitos problemas em Petrópolis, onde eles foram vendidos ao INCRA junto com o seringal. Em 1975 chegou a FUNAI. Primeiro um tal de L.H. que falou muito bonito; duas semanas depois chegou F.M., que tinha estado nas frentes de atração do Maranhão, e que era muito chegado nessas coisas de espelhinho, miçanga, etc.

Ele não confia nos brancos. Quando o branco da um é porque quer ganhar mil. Há conflitos com os políticos locais. Por causa de algumas brigas ano passado, lhe disseram: "Leva embora teus índios", e ele explicou que os índios não são dele, que um chefe está para esclarecer, ensinar, etc. (às vezes de um modo muito explícito: interrompe seu discurso para explicar o significado de algum termo em português, como "extinto" ou "folclore"). Ele tem que explicar às autoridades que ele não é dono das vontades e das consciências. Prefere ser conciliador, mas se precisar não afrouxa. Se alguém tentar meter aí a máquina (para demolir as casas dos índios na periferia da cidade) vai levar uma bala na cabeça. As filhas - meninas de poucos anos - têm ouvido disparos e vêm querendo saber se aconteceu algo com seu pai.

A identidade do chefe é um assunto discutido. Um seringueiro, a quem o chefe sabatina sobre a sua ascendência indígena, responde: "Você também não é índio, eu conheci teu pai, você é branco". Mais tarde outro hóspede chama-lhe de cearense, e ele responde aos berros que os cearenses eram trazidos presos num batelão, para servir no seringal por causa da segunda guerra mundial. O chefe comenta em outra ocasião que seu pai era um líder indígena; o dono do seringal o enviava a trabalhar longe para dar em cima da sua mãe (de fato, os Yaminawa consideram a possibilidade da colaboração seminal, e portanto da 
paternidade múltipla: o chefe tem mantido uma relação com seus parentes brancos, aos que lhe une, entre outras coisas, seu aspecto físico). O próprio chefe joga conscientemente com sua ambigüidade étnica. Para obter alguns papéis, fez no seu momento os preparativos para o serviço militar. Depois não queria fazê-lo, precisou de algumas testemunhas que declarassem que era índio e por isso não era obrigado. Livrou-se pagando uma multa. Foi ele quem trouxe os Yaminawa de Petrópolis, onde tinham sido escravos do seringal, para a terra que agora possuem no Rio Acre. Foi uma longa viagem que uns fizeram atravessando a selva e outros pelo rio, dando uma volta enorme de canoa.

\section{A voz que se faz ouvir}

Este relato segue as notas do meu diário de campo de outubro de $1992^{1}$. As notas, telegráficas, resumiam horas de agitada conversa com o então chefe dos Yaminawa do Rio Acre, com participação de outros membros do grupo. A primeira parte corresponde a diálogos acontecidos durante os preparativos e no transcurso de uma festa que já descrevi em outra ocasião (cf. Calavia Sáez 2004a). Os seguintes foram obtidos em outros momentos e em parecidas circunstâncias. Junto às informações que constam no primeiro parágrafo, anotei um comentário desalentado sobre os trabalhos do dia: "a conversa não vai por onde eu quero".

O motivo desse desânimo se descobre com facilidade revisando as notas dos dois dias anteriores. Meu interlocutor me descrevera então a sua visão dos "clãs" Yaminawa, fascinante para o etnógrafo, mas talvez idiossincrásica em excesso. Ninguém mais, além dele, parecia saber de que coisa ele estava a falar. Em lugar de esclarecer minha dúvidas, no dia seguinte o chefe tinha começado a falar de sua própria vida, com certeza interessante, mas bem alheia às experiências mais comuns dos outros Yaminawa; em suma, mais idiossincrasia.

Essa mesma suspeição perante as histórias individuais repetiu-se em outros momentos de minha pesquisa. Os Yaminawa relatavam-me com excelente disposição os shedipawó, ou histórias dos ancestrais e, também, as circunstâncias do seu encontro com os brancos. Mas punham um entusiasmo bem maior em registrar nas minhas fitas os seus cantos líricos, que eu não pedia e que aceitava de bom grado, mas não sem uma certa preocupação pelo meu estoque de fitas e pilhas. Os cantos eram ainda mais difíceis de traduzir que os mitos, e referiam-se a sentimentos e episódios amorosos do cantor-autor.

Minha reticência perante os discursos enunciados na primeira pessoa do singular é, creio, idêntica à que pode se descobrir na maior parte 
dos etnólogos que tem se ocupado dos povos das Terras Baixas da América do Sul. Não se deve, decerto, a alguma esperança de falar diretamente com um (digamos) sujeito coletivo. Minhas investigações sobre mitos, por exemplo, estavam sempre muito atentas à diversidade dos relatos, e aos pontos de vista dos seus narradores individuais. A autoria da cultura é um pressuposto firmemente assentado na etnografia da geração de etnógrafos a que pertenço. O sujeito particular é perfeitamente legítimo na hora de falar de história, de economia ou de cosmologia. O único que implicitamente se põe em dúvida é que ele esteja habilitado a falar de sua própria vida.

A autobiografia, e a biografia em geral, é um gênero praticamente inédito na etnologia do Brasil indígena, ou em geral das Terras Baixas da América do Sul, em flagrante contraste com sua abundância na tradição etnológica norte-americana. O quadro jurídico brasileiro já fornece uma pista para entender essa peculiaridade: os índios são nele coletivos, pessoas jurídicas antes que físicas. Os recortes teóricos na antropologia brasileira - incluindo nesta a da maior parte dos antropólogos estrangeiros que aqui trabalharam - sempre selecionaram imagens da totalidade, como cultura, estrutura ou grupo, e mantém uma certa suspeição perante o tradicional recurso da história de vida. Haveria talvez um receio de que o discurso autobiográfico poderia deitar a descrição no leito de Procusto do individualismo ocidental. A própria autocrítica que os estudiosos das autobiografias norte-americanas desenvolveram há muito tempo (cf. Brumble, 1990) deixou claro que a colheita e elaboração de autobiografias indígenas foi parte significativa de um processo civilizador, um recurso de educadores, indigenistas e missionários para obter "almas individuais" à medida dos requisitos psicológicos do ocidente. As autobiografias não estão naturalmente dadas na memória dos sujeitos, esperando a ocasião de serem contadas: são construídas, no caso, em um diálogo assimétrico. A autobiografia seria, no melhor dos casos, um desses híbridos que deve ser tratado com muito cuidado.

Há nessa reticência, todavia, um pressuposto não declarado, a saber, o de que se a autobiografia jogou no ocidente um papel de primeira linha na empresa de construção do indivíduo, toda autobiografia deveria ser individualista. Esse pressuposto não deveria ser de curso legal em uma etnologia que, nos seus desenvolvimentos mais recentes, definiu precisamente a subjetivação como fio condutor das cosmologias ameríndias. Se as epistemologias xamânicas insistem em ver sujeitos lá onde a ontologia ocidental indica objetos (Viveiros de Castro, 1996) e em contar os corpos como tantos outros pontos de vista, não há motivo para elidir o sujeito precisamen- 
te nessa posição que é o seu domínio típico na tradição ocidental, a do enunciador reflexivo. Se o indivíduo e sua história são, como objetos, estranhos ao pensamento indígena, essa é uma razão a mais para querer saber de que está falando um narrador indígena quando fala de si mesmo.

De fato, e matizando esse desinteresse pela autobiografia que estamos a tratar, algumas formas de discurso autobiográfico podem se encontrar em informes sobre a poesia, os cantos xamânicos ou a pregação política deste ou daquele grupo, e há pelo menos uma obra explícita e principalmente dedicada ao tema, a muito recente de Oakdale (2005). Além desta há outras, também devidas a autores americanos (Urban, 1989; Basso, 1995; Graham, 1995) que dão um destaque importante às peculiaridades do discurso indígena feito na primeira pessoa do singular.

Mas deixemos de lado minha velha avaliação das palavras do chefe Yaminawa, e reparemos no que o chefe Yaminawa de fato diz. A primeira vista - e isso contribuía também para o meu pessimismo - esse discurso se esgotava em uma política indigenista alheia a qualquer especificidade Yaminawa. Descrevia uma chefia externa, uma restrição consagrada entre indigenistas e etnógrafos para definir os limites das jovens elites indígenas habituadas a transitar na política nacional e global, tendo sempre como contrapartida alguma outra chefia (às vezes invisível) postulada como inequivocamente interna. A chefia "externa" vê-se legitimada por esse duplo movimento que explica a situação periférica do chefe e ao mesmo tempo recorta suas atribuições, preservando a autenticidade do grupo. Embora os Yaminawa como tais não tivessem sido até aquele momento objeto de muita pesquisa antropológica, estava claro que seu chefe, um veterano da política indigenista do Acre, tinha longa experiência no uso desses conceitos os quais aqueles que se ocupam de índios raramente dispensam: cultura, folclore, extinção, clãs... Todos os seus relatos vinham formulados em um idioma cheio de sentido para seus interlocutores brancos: confirmavam uma doutrina, segundo a qual a história recente dos povos indígenas é a história de suas relações com as agências da sociedade nacional, sem mais relação com o interior do grupo que a progressiva erosão à qual os conteúdos locais são submetidos.

Como sabemos, a etnologia recente tem alterado sensivelmente essa visão das relações entre interior e exterior (cf. por exemplo Albert; Ramos, 2002), mostrando as sociedades indígenas como máquinas de absorver exterioridade e não mais como frágeis reservatórios de identidade (Fausto, 2001; Viveiros de Castro, 2002; Calavia Sáez, 2003). De fato, essa idéia de um líder definido em uma idade temporã, precisamente, pelo seu desenraizamento familiar e pelo seu exílio temporário entre os brancos 
tem uma longa tradição local. Relatos de outros Yaminawa, referidos a épocas anteriores, coincidiam em sublinhar que a hostilidade e a desconfiança mútua entre índios e brancos só tinham sido superadas pelas boas artes de um menino raptado pelos brancos, que tinha aprendido a língua destes servindo assim de mediador entre uns e outros. É o mesmo relato que podemos encontrar já no século XVIII na boca dos missionários franciscanos que se ocupavam dos grupos Pano do Ucayali ${ }^{2}$. O chefe indígena é por definição um semi-estrangeiro e um recém-chegado. $\mathrm{O}$ interessante, no caso, é que seja precisamente um chefe indígena quem enuncie essa doutrina. Ela se opõe a esse ideal de liderança nascida do próprio chão que faz parte do ideário das ONGs, propondo em seu lugar uma espécie de liderança que paira livre sobre esse chão, tentando lançar nele suas raízes. Um chefe à procura de um povo, ou a rigor da oportunidade de criá-lo, de "unir os Yaminawa como um povo só" o que, como ficou claro em outros diálogos, poderia acontecer com a ajuda de um projeto talvez financiado por ONGs européias.

Não sejamos mais deconstrucionistas que o necessário: esses cálculos não são resultados espúrios do ativismo pós-moderno. Para começar, eles perpetuam o velho sistema de aviamento da época da seringa, que, além de varrer do mapa numerosos grupos indígenas, auspiciou também a criação de outros grupos por chefes indígenas mais ou menos aliados aos donos dos seringais. Mesmo longe destas relações perigosas, não é fácil encontrar nas Terras Baixas, fora de alguns poucos casos bem delimitados (Xingu, grupos Ge, etc.) a noção de um grupo preexistente ao seu chefe. Antes o grupo deriva, nos seus limites e na sua coesão, de uma perspectiva individual que consegue entrelaçar relações de parentesco em uma unidade provisória. O chefe não é o gestor da socialidade: é quem a atualiza, criando o grupo a partir de laços potenciais. Essa perspectiva individual pode ser também determinante no que diz respeito à estrutura conceitual do grupo. Quando comecei a organizar meus dados de campo tive que encarar, finalmente, aquela descrição idiossincrásica dos clãs yaminawa, muito provavelmente uma invenção do chefe que não encontrava eco na memória de nenhum outro nativo, e que só se viu, enfim referendada, quando o chefe a quem estou me referindo abandonou o cargo e foi substituído por outro. Na sua nova posição, o novo chefe (discreto opositor do anterior) começou a enxergar nessa invenção um perfil do grupo que até então lhe escapava.

Eis aqui uma observação que vale a pena reter. Para além do teor autobiográfico de alguns gêneros de expressão indígena - como o dos cantos Yamayama, ao qual já me referi - aparece aqui uma variedade de 
relatos ligada a uma posição política, como se a expressão autobiográfica fosse uma das funções da chefia. O chefe conta sua vida, porque é em virtude dela que o grupo como tal chegou a existir.

O indigenismo católico de esquerda, que dava um apoio decisivo à organização indígena em que os Yaminawa participavam e teve um visível protagonismo em todo o processo político indígena dos últimos decênios, evoca com freqüência no seu discurso o exemplo dos hebreus, de sua escravidão e da sua migração a procura da terra prometida. Termos como "cativeiro" e "caminhada" são essenciais no seu vocabulário: a emancipação dos povos indígenas é comparável a um Êxodo sem Moisés. A história de um chefe de identidade ambígua, que se cria entre os inimigos, que se revolta ante o trato que os seus recebem deles, e que lidera a migração do seu povo para uma nova terra, têm a virtude de preencher essa lacuna. Afirma o protagonismo de uma nova elite indígena, mediante um relato autobiográfico que reúne os ecos de duas tradições.

\section{Singular e plural}

Davi Kopenawa Yanomami provavelmente dispensa apresentações. Ele é o paradigma de um novo tipo de liderança indígena (Albert, 2002; Graham, 2002) e o leitor desta revista o conhecerá com certeza por alguma de suas numerosas apresentações escritas, faladas ou filmadas. Neste momento, referir-me-ei somente a dois breves textos que ele publicou numa coletânea sobre os 500 anos da "descoberta" do Brasil (Kopenawa, 2000). O conjunto vem precedido de uma apresentação do autor, assinada pelo antropólogo francês Bruce Albert. Junto a um resumo das campanhas nas quais ele participou ativamente, como defensor dos povos indígenas e da ecologia e das distinções de que se fez credor, está uma breve biografia da qual extraio o seguinte:

Criança, Davi Kopenawa perdeu... a maior parte dos membros de sua família. Em seguida sofreu, e depois rejeitou, o proselitismo dos missionários da Missão Novas Tribos do Brasil, abandonando na adolescência sua região natal para trabalhar na Fundação Nacional do Índio como intérprete. No começo dos anos 80 , fixou-se em Watoriki, ali se casando com a filha do líder da comunidade, xamã renomado que o iniciou e, tradicionalista convicto, permanece seu mentor. Davi é hoje a um só tempo chefe do posto indígena Demini e um dos mais influentes xamãs de Watoriki.

O texto que segue, já assinado por Davi Kopenawa, registra dois modos de enunciação bem diferentes. A primeira parte, Sonhos das origens, é uma vívida pintura do mundo dos espíritos: 
Os xapiripe dançam juntos sobre grandes espelhos que descem do céu. Nunca são cinzentos como os humanos. São sempre magníficos: o corpo pintado de urucum e percorrido de desenhos pretos, suas cabeças cobertas de plumas brancas de urubu rei, suas braçadeiras de miçangas repletas de plumas de papagaios, de cujubim e de arara vermelha, a cintura envolta de rabos de tucanos.

Como o autor indica, os espíritos são acessíveis somente após um aprendizado xamânico longo e difícil. A visão é uma experiência pessoal e em boa parte incomunicável: as crianças ouvem os cantos dos xamãs e querem ver por sua vez os espíritos. A descrição que ele faz do mundo dos xapiripe, no entanto, não é o testemunho individual de alguém que viu. Fala dos espíritos em termos absolutos, e refere-se, sobretudo, à relação entre eles, os espíritos, e nós (no caso, os yanomami) que "guardamos dentro as palavras dos ancestrais".

A segunda parte descreve os temores e as dúvidas do autor a respeito dos homens brancos e o contraste entre os modos branco e indígena de, digamos, estar no mundo. Esta seção, em contraste com a primeira, dá lugar a um discurso em primeira pessoa, pleno de referências emotivas:

Quando aqueles estrangeiros entravam na nossa habitação, minha mãe me escondia debaixo de um grande cesto de cipó... Todos os bens dos brancos me assustavam também: tinha medo dos seus motores, de suas lâmpadas elétricas... de seus sapatos, de seus óculos e de seus relógios....

Junto ao terror que produzem estes seres esbranquiçados e peludos, que roubam as crianças e provavelmente são canibais, insinua-se também a curiosidade quanto aos seus objetivos: "me perguntava também por que aquelas pessoas tinham vindo até a nossa casa". Só depois de chegar à idade adulta, Davi passou a entender: "sabia o que os brancos queriam ao penetrar na nossa terra". Filhos, como os próprios Yanomami, de Omama, e oriundos também da selva, o pensamento dos brancos está cheio de esquecimento e têm se empenhado em destruir as selvas, em buscar sob a terra as matérias perigosas que o Criador lá tinha escondido, e em produzir com elas mercadorias. Nas suas viagens à Europa, Davi teve oportunidade de avaliar o seu caráter insaciável e excessivo, oposto a essa relação não conflitiva que os Yanomami mantêm com essa terra em que nasceram (e que não pretendem ter "descoberto"). Em parte o segundo relato de Davi é comparável ao primeiro: descreve com vigor um estranho mundo infernal que poucos dos seus conterrâneos tiveram oportunidade de conhecer, mas também resume vivências, podemos supor, amplamente compartilhadas pela maior parte dos Yanomami que presenciaram desde a infância a paulatina invasão dos homens brancos. À diferença do texto sobre os xapiripe, a primeira pessoa do singular aparece neste relato marcando os 
momentos chave de um descobrimento do outro. Davi Yanomami está no ponto médio entre o reconhecimento e o desconhecimento mútuos.

As semelhanças entre o relato de Davi Kopenawa e aquele que iniciou este artigo são triviais. Afinal, todas as vidas se parecem, ainda mais aquelas que compartilharam uma experiência histórica semelhante, no caso, uma experiência de agressões, destruição e projetos proselitistas. Mas essa naturalidade é a ilusão comum de todos os relatos e, em especial, dos autobiográficos. Dos Yaminawa aos Yanomami a perspectiva se inverte. A trajetória de Davi no mundo dos brancos é aqui narrada por um antropólogo, não pelo protagonista. Quando ele mesmo toma a palavra, fala da chegada dos brancos. Suas saídas em direção a eles são, digamos, janelas que lhe permitem entender a distância entre ambos os mundos. Embora a posição mediadora do narrador possa parecer a mesma, opera em sentidos contrários. O líder Yaminawa explica aos seus liderados como são os brancos, às vezes com especial destaque o que os brancos acreditam saber sobre eles, índios; o Yanomami, explica antes aos brancos o que os índios podem pensar a respeito deles.

Nada bom, aliás. Esse discurso sobre a anomalia intelectual e moral dos invasores remonta aos mais antigos testemunhos desse contraste e em concreto evoca intensamente o diálogo de Jean de Léry com um ancião tupinambá que não entende como os franceses empreendem tão longas viagens pela cobiça de pau-brasil. Em qualquer caso, com seus discursos autobiográficos, o chefe Yaminawa e o líder Yanomami qualificam-se a si mesmos como exceções necessárias em uma situação de diferença. Mais do que chefes são diplomatas, quer dizer, essa única autoridade efetiva em condições trans-fronteiriças: a travessia habilitou-lhes para tanto.

No seu contexto histórico, essa afirmação é menos banal do que parece. O antigo regime indigenista, seja sob os auspícios mais ou menos positivistas da FUNAI ou do SPI, seja sob controle dos missionários de diversas ordens, prescindia de autobiografias. Sob direta supervisão dos seus agentes, os índios existiam, exclusivamente, como coletivo e do chefe indígena esperava-se que fosse um homem, ou talvez uma mulher, com farta autoridade local. Que esses chefes fossem mediadores com vidas cul

turalmente híbridas e que sua autoridade derivasse eventualmente desse papel mediador não tinha maior importância, nem era, portanto, objeto de registro. Em certo sentido todos os índios eram mediadores, já que, selvagens catequizados, estavam em trânsito coletivo a um estágio superior de civilização. A mediação passa a ser visível em um panorama incipientemente multicultural como o brasileiro, em que a diferença é 
um requisito indispensável para conseguir uma personalidade política e no qual a importância dos fluxos de recursos e de informação faz de todo tradutor um líder em potência ${ }^{3}$.

A alternância entre falas na primeira pessoa do plural e do singular, que encontramos nos escritos de Davi Yanomami tem seu paralelo em outro aspecto do seu discurso, o uso lado a lado de termos tomados do ambientalismo ocidental e do xamanismo local (Graham, 2002, p.201205). Ou também no uso de declarações em língua indígena para marcar momentos específicos em um discurso feito na língua nacional ${ }^{4}$.

A política étnica global, em si um oxímoro, multiplica os oxímoros à sua volta. Necessita de enunciadores construídos como indivíduos para servir como representantes de uma comunidade do mesmo modo que precisa de divergências (culturais e lingüísticas, inseridas no momento certo do discurso) para servir de denominador comum.

\section{O tradutor deteriorado}

No quadro de um projeto sobre história recente dos índios no Brasil ${ }^{5}$, meu grupo de pesquisa realiza uma série de entrevistas com líderes de grupos indígenas do estado de Santa Catarina. O objetivo é indagar sobre as reformulações da autoridade política e da chefia desde o ponto de vista dos seus agentes. Partimos da premissa de que essa autoridade política tem sofrido uma alteração significativa desde que o campo indigenista deu espaço a novos atores, especialmente a ONGs nacionais e internacionais. Interessa a descrição do processo que levou esses protagonistas à liderança e, também, do próprio conceito de liderança, que parece sincretizar todas as figuras de autoridade - cacique, tuxaua, pajé - previstas na relação colonial, mas sem se prender a limites precisos.

Todos esses propósitos apontavam, é claro, ao relato autobiográfico e as entrevistas deram aço precisamente a esse tipo de expressão. Os resultados no estado absolutamente incipiente da pesquisa são quase unânimes em evitar essa via. Sujeitos com histórias pessoais ricas e dramáticas prescindem de toda referência a elas para falar em termos absolutos ou em primeira pessoa do plural do seu povo, suas crenças ou os problemas territoriais ou políticos da hora. As referências a circunstâncias pessoais são elididas, mesmo quando o entrevistador, a certa altura do diálogo, pergunta nesse sentido. Num caso (a entrevista ainda está em processo de transcrição) a indagação pela vida pessoal do narrador obtém como resposta um relato genealógico que remonta à sua bisavó. Esta 
evitação realça as expressões autobiográficas antes descritas: nem todos os líderes indígenas estão dispostos ou interessados para falar de si.

Há, no entanto, uma exceção à norma. Leonardo Werá Tupã, um jovem líder de 34 anos, com um longo currículo como cacique de aldeia, representante dos Guarani em diversos foros, professor de língua Guarani e ator de cinema. Ele tem, sim, alguma coisa a dizer sobre sua própria trajetória ${ }^{6}$.

Depois de algumas considerações gerais sobre a importância do diálogo com os brancos, o relato ocupa-se de legitimar seu papel à luz das tradições:

Na hora do batizado, os mais velhos contam como que esse menino, quando crescer, como é que ele vai ser. Como será o comportamento dele. E isso tudo é contado quando é pequeno. Então, no meu caso, desde pequeno, desde os dois anos de idade... a minha família já sabia que vai chegar o momento que eu iria fazer tudo pra defender o meu povo...

Mais uma vez, o líder não aparece como um administrador de relações sociais, mas como um sábio capaz de reunir e comparar conhecimentos diferentes; e, sobretudo, de traduzir:

Então eu comparava as coisinhas contadas pelos mais velhos e também contadas através dos livros. Começou a viajar mesmo, sair fora, participar de uma reunião nacional Guarani, onde todos os mais velhos, caciques, lideranças se reúnem. A minha primeira participação foi quando tinha 14 anos de idade. Os mais velhos na época, meu avô, confiava muito e assim deixava eu viajar, sair, representar a aldeia. E com 17, 18 anos de idade, então, eu já fazia parte de uma organização. Seria, a tradução dela seria "Assembléia Geral dos Guarani". E onde então eu era um tradutor e secretário também dessa organização. E na época os mais velhos também não falavam português, então eu fazia a tradução.

A necessidade de traduzir vem dada por uma ignorância voluntária: os Guarani conhecem os brancos há muito tempo, e desconhecer sua língua é uma decisão mais do que uma eventual carência:

Antes era, o Guarani não se preocupava muito com a escrita. De escrever, de ler, de conhecer a escola do homem branco. E isso, assim, o contato, de aprender assim era considerado uma coisa assim ruim. E seria afetar a pureza do Guarani.

A diferença dos líderes amazônicos citados no começo, Leonardo estabelece alguma diferença entre a condição de tradutor e a liderança:

A minha pessoa em si não tem vontade de talvez ficar no poder, assim como Cacique. Mas é porque eu sinto que ser um Cacique ela tem um limite. E eu já não gosto de limite. Eu gosto de ser livre.

De fato, Leonardo ocupou por algum tempo a função de cacique, para a qual deviam ser obstáculo sua juventude e ainda mais sua falta 
de vínculos familiares. Alguma vez recebeu, além disso, acusações de não ser Guarani, de ser branco. Em certo modo, ele as admite:

Tem que estar mais ligado na sua comunidade. Eu já no meu caso então eu já não gosto de ficar muito parado. Parece que a minha ligação é mais externa.

Ainda mais, esse vínculo externo afeta negativamente as capacidades xamânicas adquiridas na adolescência, quando tinha revelado e desenvolvido capacidades como curador:

A partir de 15 anos de idade eu... esse poder que eu tinha então, sumiu, né. Não consegui mais controlar, porque isso requer muito da pureza, né, espiritual e físico e mental. Então é muito difícil ficar controlando isso. E no meu caso, então, com esse contato com o homem branco, então, isso perde, né?. Porque a concentração que... da mente, tem que ta totalmente voltado à espiritualidade. Já não pode ter mais um pensamento antes negativo. A pessoa tem que ser pura, tem que ser uma verdadeira, verdadeiro possuidor do bem.

Leonardo Werá Tupã fornece a outra cara da moeda dos exemplos iniciais, em que a exterioridade não oferecia empecilhos para a chefia ou para o desempenho de funções xamânicas de prestígio. A ascensão de líderes indígenas em virtude da mediação entre os grupos e as agências internacionais de apoio é muito rara no sul do Brasil, uma região que carece do apelo exótico da Amazônia. Embora muito numerosa para a média nacional, a população indígena meridional tem muito pouco espaço na política multicultural brasileira. Nenhum dos seus principais conglomerados tem se inserido com sucesso nesse intercâmbio de diferenças que exige uma imagem e uma tradição distintiva como capital político. Os Kaingang, velhos clientes dos órgãos indigenistas oficiais, têm se caracterizado por uma atuação abertamente política (com pouca ênfase no cultural) e uma decidida incursão nos modos brancos de saber e poder: vários Kaingang ocupam cargos políticos municipais ou obtiveram títulos universitários. Não faltaram entre eles projetos de resgate cultural, como as tentativas de reativar o velho ritual do kiki, mas o esforço tem sido descontínuo e polêmico e seus resultados limitados. Pela sua parte, os Guarani têm evitado tradicionalmente a visibilidade e o controle por parte dos órgãos oficiais, preferindo se manterem desconhecidos nos interstícios do mundo dos brancos, instalando suas aldeias nas margens das grandes fazendas, em áreas residuais de selva ou, enfim, à beira das rodovias. Para a opinião pública, os Guarani são índios do passado, e vivem essencialmente na memória das missões jesuíticas. O denso patrimônio cultural Guarani manteve-se reservadamente alheio ao mercado simbólico da indianidade. Embora a situação esteja mudando atualmente - as atividades de investigação e de 
difusão cultural Guarani têm se multiplicado nos últimos dez anos - os Guarani ainda encontram um obstáculo para as suas reivindicações na noção muito estendida de que eles não são suficientemente índios: paradoxos da autenticidade ${ }^{7}$.

A autobiografia de Leonardo Werá Tupã, semelhante na sua forma a dois líderes amazônicos, decanta-se em um sentido diferente em função desse contexto. O conhecimento do modo de vida dos brancos é dificilmente compatível com a atualização da tradição e o leva à afirmação de um valor típico de seus aliados urbanos, a liberdade individual que no caso significa, apesar de freqüentes declarações em contrário, pouca disposição para formar uma família e se ligar permanentemente a uma aldeia. O esquema narrativo é quase o mesmo, mas a história narrada é muito diferente.

\section{Estranho em qualquer ninho}

O último relato de que nos ocuparemos põe à mostra mais uma vez. Justino Sarmento Rezende, índio Tuyuka, sacerdote católico e membro da ordem salesiana ${ }^{8}$. Cursou o mestrado em educação na Universidade Católica Dom Bosco, sob a orientação de um historiador de prestígio, ligado também à Igreja Católica. Seu escrito Aventuras de um indio, publicado no número anterior da Tellus ${ }^{9}$ oferece uma série de breves esboços de suas experiências pessoais, todas, menos uma, como sacerdote. A forma autobiográfica se adequa ao caráter testemunhal do escrito. Também, decerto, serve para dar um ar casual e simples, uma certa modéstia cristã, à medida da profissão do autor, a um texto pleno de complexidade e refinamento.

O índio-sacerdote reflete sobre problemas de classificação. Na primeira anedota, descreve a perplexidade de umas freiras da cidade de São Paulo ante as quais ele celebra uma missa, substituindo o capelão habitual. Sua condição de índio provoca surpresa:

Antigamente os brancos é que iam evangelizar os índios e agora os índios vêm evangelizar os brancos!

Na segunda anedota, Justino narra suas diferenças com outros agentes de sua igreja, em um aeroporto onde ele e outros eclesiásticos encontram-se em trânsito para um congresso. Cada grupo porta camisetas que identificam sua procedência. Chama a atenção que, em um país onde a apresentação pública dos índios caracteriza-se pelo uso intenso de marcadores de identidade, seja precisamente ele, um padre-índio, quem careça deles: “você, também está indo? Onde está o seu distintivo?”. 
Outro sacerdote (negro, para completar os paradoxos de uma igreja em pleno ensaio multicultural) apresenta-o ao seu bispo, que o olha com reticência: “Ele é padre? Eu não confio nos índios!".

$\mathrm{O}$ autor reconhece sua anomalia:

Este tipo de sacerdócio da igreja não existe nas culturas indígenas. Está existindo agora com a evangelização. Com certeza deve criar ciúmes para os herdeiros históricos deste sacerdócio... Imaginemos que um "branco" queira tornar um pajé, xamã, mestre de danças, nós não veríamos com os bons olhos.

Uma dúvida preocupa o narrador: quiçá a mensagem que ele deve transmitir encontre um obstáculo na sua condição de índio. O público das suas missas ou suas pregações pode não reconhecer o cristianismo em uma doutrina que lhes chega por um veículo tão incomum. O meio é a mensagem?

Na terceira anedota a perspectiva se inverte. Depois de se referir às barreiras lingüísticas que habitualmente separam os missionários salesianos dos seus fiéis, descreve a surpresa de uma criança que ouve a sua pregação em língua indígena::

a criança ficou observando atentamente e por muito tempo... a criança olhava para mim (padre), olhava para as pessoas e olhava para a mãe. Esta atitude era como se ela dissesse: será que eles estão vendo o que eu estou vendo? Ou eles não estão vendo?

A mãe da criança disse que na hora em que todos se sentaram para ouvir a minha homilia, a criança continuou olhando para mim (padre) e depois perguntou para a mãe: mamãe, ele é padre? A mãe respondeu: Sim, meu filho. Ele é padre! A criança perguntou para a mãe: Por que ele está falando em tukano? A mãe respondeu: Porque ele é nosso parente. Por isso, ele fala em tukano!

O autor retorna às suas dúvidas:

será que a língua tukana usada nas missas diminui a fé do povo indígena? Será que a língua portuguesa ajuda mais a fé do povo indígena? Muitas vezes dá impressão que sim. Uma autêntica pregação tem que ser feita em português... Deus não atende pela língua indígena.

Mas ele está longe de afirmar a opção do catolicismo contemporâneo pela comunicação. Antes, considera outras funções - quiçá mais tradicionais, do ponto de vista indígena - da língua sagrada:

Penso que para os povos indígenas que estão acostumados com rituais, danças... que usam línguas muito antigas e, por isso, incompreensíveis, uma missa com linguagens incompreensíveis não há grandes diferenças. O importante é que os agentes dos rituais saibam falar aquelas línguas, pouco se importam se os restantes dos participantes 
estão entendendo ou não. São ritos e suas linguagens não precisam ser entendidas, mas repetidas.

No item a seguir, os contrastes não se dão no seio do catolicismo indígena, mas dentro do movimento indígena. O autor assiste à I Conferência dos Pajés do Amazonas, com alguns receios. Alguns deles perfeitamente tradicionais:

Os meus avôs haviam me ensinado que quando têm muitos pajés, principalmente, quando são de diferentes etnias, teria que ter medo ou pelo menos estar protegido das forças negativas que possam sair deles. Diziam mais, o pior sempre sobra para quem é mais fraco. O mais fraco neste caso é aquele que não é pajé. Como até hoje eu uso o benzimento de meus parentes para a proteção da minha vida, eu usei e fui.

Mas há também receios de outro tipo:

Entre os pajés reconhecidos, havia pajés de 'nome', oportunistas. Estes últimos andam pelas cidades enganando a boa fé do povo "branco". Como eu já os conheço, quando me viram ficaram se disfarçando. Mas, como andavam cheios de enfeites, as atenções das câmeras voltavam-se mais para eles do que para aqueles que eram realmente pajés. Além de vários indígenas, homens e mulheres, havia muitos representantes de instituições governamentais, das ONGs e representantes de organizações indígenas. Eles ocupavam mais espaços e apareciam mais que os próprios pajés. ... Quem sabe se eles se consideram pajés?

Em meio a essa celebração das tradições nativas, sua condição de sacerdote católico índio resulta conflitiva. Uma mulher, advogada e militante do movimento indígena, se lha recrimina:

Nós estamos sempre combatendo os missionários e vocês se tornam padres? Não sabem que eles que destruíram as nossas culturas?

Inicialmente perturbado por essa agressão, o autor se recompõe e responde, defendendo sua própria alternativa:

O fato de eu ser índio padre e estar engajado no Movimento Indígena para ela não contava. Ela mostrou a visão estereotipada historicamente construída na mentalidade indígena: todo padre é contra os índios, é destruidor das culturas... Se eu fosse olhá-la somente como advogada, não a veria como defensora dos povos indígenas, pois muitos advogados advogam em favor dos "brancos" e contra os povos indígenas.

As anedotas seguintes focam as peculiaridades do seu desempenho como padre e as dúvidas que seu estilo levanta entre os agentes brancos de sua própria igreja, os seus superiores ou supervisores. Um deles é outro sacerdote, que, ciente de sua própria dificuldade para comunicar-se, ou para entender as atitudes dos fiéis, admira as habilidades de Justino. Mas mesmo assim duvida de sua idoneidade: 
Padre Justino, as suas missas são bem animadas. O povo gosta muito. $\mathrm{O}$ povo entende bem o que vocêfala. O que eu quero dizer para vocêé: “Você não pode fazer o povo dar risadas na missa! A missa não é para isso!"

Em outro caso, o autor comenta - como já fizera outras vezes - o lugar periférico que a instituição lhe reserva como sacerdote indígena, esta vez por ocasião de uma reunião catequética:

No dia da assembléia escolheram num lugar afastado da cidade e no meio de uma floresta. Eu gostei. Índio que não gostasse do mato não seria bom índio! Só o ambiente já era um grande recurso metodológico, pedagógico, catequético, ecológico. Só bastava colocar Deus no meio de tudo isso, pois o índio já estava lá (eu).

Mesmo neste lugar já razoavelmente "selvagem" seus métodos são objeto de restrições pela "assessora" que supervisiona o encontro:

Padre Justino, você está na profissão errada, você era para ser palhaço! Fala com mais seriedade para os catequistas, pois nós não viemos aqui para brincar!

O autor, em um comentário ao episódio anterior, defende seu método: dão risadas, pois estão entendendo o que está sendo dito. Segundo a filosofia indígena (Tuyuka) se estão dando risadas ou conversando na hora que eu estou falando, é sinal que estão entendendo o que eu estou dizendo. O silêncio nem sempre é sinal da compreensão.

O parágrafo é interessante, sobretudo se o entendemos à luz de um detalhe que se repete várias vezes na narrativa: um protagonista perplexo (a criança que vê um padre pregar em língua tukano, o padre branco que vê os índios rirem durante a missa) olha para um lado, olha para outro... Em um caso, para saber se os outros estão vendo o que ele está vendo, no outro inquirindo pelo significado do que está vendo. Justino Rezende não é um líder tradicionalista que reivindique o respeito dos brancos ante a sabedoria tradicional do seu povo, mas um inédito mensageiro da religião oficial dos brancos. Talvez por isso mesmo esteja livre para identificar sua diferença como índio não em uma mensagem, mas no modo de interlocução. O diálogo que os sacerdotes brancos esperam parte da relação entre um sujeito enunciador e um enunciado-objeto (o qual deve ser corretamente recebido pelos ouvintes). Justino propõe em lugar disso uma conjunção de sujeitos enunciadores, cujo valor não está necessariamente no controle do significado.

A compreensão pode se manifestar em risos, ou nas palavras de uma língua incompreensível: o dono da palavra deixa que outros falem. O relato de Justino Rezende é, dentre os que se comentam neste artigo, aquele que mais se prende a esse estilo citacional que segundo vários autores (Urban, 1989; Viveiros de Castro, 1986; Oakdale, 2005), caracte- 
riza o discurso ameríndio, autobiográfico ou de outro tipo. Deixa em um segundo plano, recurso digno de nota em um relato sobre a própria vida, o discurso em primeira pessoa para destacar, até tipograficamente, reservando-lhe lugar de epígrafe, o que outros dizem a seu respeito.

Os últimos capítulos do texto assumem, quiçá involuntariamente, um certo tom sibilino. No primeiro, narra suas inquietações ao enfrentar aulas de inglês sem ter, à diferença dos seus companheiros de turma, noção alguma dessa língua:

O professor era um padre norte-americano. Falava muito mal o português, mas era bom em inglês. Era a sua língua.

Quando o professor pede ao grupo uma redação em inglês, Justino, incapaz de fazê-la, opta por escrever em tukano. O professor contemporiza: "você pode ser muito bom na sua língua, mas em inglês você é péssimo!" e lhe dá uma nota média.

O último capítulo narra os jogos da infância, quando ele com outros jovens vizinhos da aldeia ocupavam-se em caçar peixes e lagartos com arco e flecha, em manobras de perseguição e cerco que a rigor se assemelhavam a pequenas operações bélicas. Justino descreve sua inabilidade e sua raiva, quando um dos seus companheiros lhe cobra sua torpeza. Irritado, ele responde atirando-lhe uma flecha, que vai cravar-se na barriga da perna do menino. Este retira a flecha sem maiores réplicas, mas o autor retira-se intimidado, com medo de posteriores vinganças. Afastase assim de seus companheiros, até que poucos dias depois vão chamá-lo de novo para brincar e ele pode se reintegrar ao grupo. "Eu me arrependi de ter flechado o menino" é a frase que encerra o relato.

Malgrado seu aspecto casual, a narração de Justino Rezende está firmemente estruturada. Em diversos contextos, todas as anedotas abordam sua condição anômala. Um índio-sacerdote é algo próximo de uma aberração para os membros da Igreja, para os fiéis indígenas e enfim para os militantes de um movimento indígena a qual sente-se também parte. Indiferente aos programas de teologia da enculturação (à qual o próprio autor, porém, adere) essa anomalia perpetua uma história em que índio e sacerdote pertencem a séries opostas. Não é uma discriminação sem sentido: é referendada tanto pelo exo-lingüismo do ritual tukano, quanto pela identificação de Deus com uma cultura e uma língua, no caso a portuguesa. $\mathrm{O}$ sentido exige diferença. Um sacerdote indígena é aberrante, como o seria um pajé branco. Um sacerdote dirigindo-se aos índios em tukano talvez seja tão suspeito quanto um pajé "de nome" que se dirige aos brancos em português. O interesse do texto encontra-se, sobretudo, neste liso ceticismo a respeito da tradução expresso por alguém inconfundivelmente destinado 
à mediação. Provavelmente, a resolução do paradoxo está no conceito de enculturação que interessa, como teólogo e como estudante de pós-graduação, ao autor do texto. Na ordem narrativa parece apontar para os dois últimos relatos em que o autor opta por uma rejeição explícita da comunicação. Incapaz de escrever em inglês, escreve em tukano; incapaz de executar uma caça lúdica, recorre a um pequeno ensaio de guerra. No episódio da flechada, no qual, enfim, apresenta-se um cenário plenamente índio, na selva, com arco e flechas, Justino parece sugerir uma anomalia que está na origem das seguintes: o caçador incapaz se transformará em sacerdote dúbio. Mas a incongruência mostra aí suas virtudes: o companheiro não se vinga, o professor de inglês lhe concede uma nota aceitável. Essas duas anedotas podem ser ilustrações da filosofia tuyuka da que ele mesmo falava pouco antes, não importa a transmissão da mensagem mas a expressão simultânea dos sujeitos. Se a mensagem cristã pode ser bloqueada pela identidade étnica do mensageiro é porque, talvez, a mensagem importe menos que a presença e a entidade dos interlocutores. Neste sentido, a opção de Rezende não pode senão lembrar essa situação do xamã do Alto Rio Negro (Buchillet, 1992) que canta sua palavra eficiente em um lugar onde ninguém lhe ouve.

Em princípio, o sacerdote tuyuka apresenta-se em uma posição topológica idêntica à dos anteriores protagonistas. O chefe yaminawa, o xamã yanomami e o jovem cacique guarani são tradutores, embora a direção e o valor das traduções sejam diferentes. Mas a atitude de Rezende inclui uma peculiaridade que não deixa de ter vínculos interessantes com seu fundo cultural tukano - a sua é uma tradução impossível, porque tudo o que vier a dizer será sempre apagado pelo que ele é.

\section{Em conclusão}

A autobiografia é um campo de vastas possibilidades na etnologia brasileira. Seja a partir de novas investigações, seja mediante a compilação de relatos espalhados em publicações já existentes ou, mais freqüentemente, nos materiais de campo dos etnógrafos. Em conjunto, pode acrescentar dimensões importantes à etnologia das Terras Baixas e contribuir com a correção de alguns vícios etnográficos herdados. Uma descrição dos modelos ou das fronteiras sociais enunciada desde um ponto de vista absoluto, dificilmente combina com a noção atual de sistemas egocentrados, como os do dravidianato amazônico, nem com o tratamento perspectivista da informação cosmológica. Uma maior atenção ao discurso autobiográfico traria mias visibilidade às versões contrastadas 
seja dos modelos sociais gerais, seja dos regimes de aliança, seja das práticas xamânicas e ofereceria panoramas inéditos de suas transformações.

Mas o tema deste artigo é um segmento muito específico deste campo autobiográfico: aquele que tange à liderança, ao seu exercício e às novas formas que está adquirindo. A importância do relato autobiográfico neste espaço não pode ser desdenhada. Se no Ocidente, escrever memórias tem sido, tradicionalmente, uma das ocupações favoritas dos homens de estado em fim de carreira, poderia muito bem se dizer que no campo da política indigenista e indianista o relato autobiográfico pode estar se convertendo em uma das premissas para tal carreira. Não podemos esquecer que a líder indígena mais destacada no mundo contemporâneo, Rigoberta Menchú, Prêmio Nobel da Paz, porta-voz indígena internacionalmente reconhecida e diretora de uma poderosa ONG na Guatemala, seu país de origem, deve, em boa parte, essa posição à ampla difusão da autobiografia (Menchú, 1985) que escreveu em colaboração com Elizabeth Burgos-Debray. As críticas que já foram feitas ao relato, especialmente em Stoll (1999), que gerou uma longa polêmica internacional, apontam alguns dos fatores que dão ao relato autobiográfico essa relevância. Na sua crítica a Menchú, Stoll, aparte de discordar dela em alguns juízos sobre a situação política na Guatemala, previa à aparição da guerrilha, indica que a líder indígena está assumindo como próprias as experiências que o povo que ela quer representar viveu em diferentes momentos e lugares. Tal ou qual massacre narrado como algo testemunhado com os próprios olhos aconteceu realmente, mas longe da protagonista. Ela constrói para si, sempre segundo Stoll, uma identidade de proletária indígena iletrada sobre um currículo bastante diferente que inclui um longo período de educação formal em um colégio católico.

Sem entrar nos detalhes da polêmica, parece que há um ponto em que defensores e detratores concordam: Menchú fala de si em nome de outros. A representante dos indígenas guatemaltecos singulariza uma primeira pessoa do plural. Este modo de escrever se distancia da tônica geral das autobiografias norte-americanas, que têm objetivos diferentes e são mais convincentemente individualistas, em função do público ao qual são destinadas e da idéia que esse público faz do contexto da história. Como Menchú, os líderes indígenas brasileiros falam para um público que entende os índios como coletivos, afastados (para o bem e para o mal) dos parâmetros individualistas da sociedade global, público que, no entanto, deve ser persuadido da necessidade e da possibilidade de modificar as relações entre esse coletivo local e a sociedade global. Em outras palavras, um sujeito autobiográfico é um dos recursos mais efetivos para inserir convincentemente 
dentro da história contemporânea povos que não desejam continuar limitados pelo ostracismo da primitividade, mas que devem conservar essa marca da primitividade ou da autoctonia como capital político. Expondo ao público o eu incomum do líder, garante-se a comunidade do nós.

Deve se dizer que, à diferença do que pode estar acontecendo, inclusive em outros países da América Latina, onde essa prática já tem dado lugar a um número apreciável de publicações, a autobiografia dos líderes indígenas brasileiros está longe de constituir um gênero. As existentes não estão publicadas, e sobre elas pesa, talvez, uma expectativa semelhante à que recobre outros itens mais tradicionais da autoria indígena: a que diz respeito ao seu valor comercial e ao seu possível esbulho, aos perigos do domínio público. As que foram publicadas não estão indexadas como tais, muito menos acessíveis a um público que não seja o da própria prática indigenista. Os autores das autobiografias não lêem uns aos outros e assim faltam muitos dos expedientes que contribuiriam de praxe na constituição de um gênero, a mimese, a emulação, a variação. De tudo isso resulta a brevidade das narrativas e sua escassa densidade. Ainda assim, pode-se notar nas precedentes análises sumárias, que essas narrativas não são ditadas exclusivamente pelas exigências que um público global (embora às vezes representado por um único entrevistador) impõe ao narrador.

Com os escassos elementos que põem em ação, essas autobiografias conseguem ser diferentes entre si e essa diferença remete a práticas e classificações locais. Em particular, remetem aos diversos modos de relação com a alteridade que, para os Yaminawa, os Yanomami, os Guarani ou os Tukano, definem o valor e o papel do mediador. As autobiografias indígenas nos dizem muito sobre a política indígena do multiculturalismo. Mas dizem também algo mais. Os regimes de subjetivação ameríndios, cuja relevância na hora de se apropriar dos objetos, das instituições ou dos credos ocidentais que se lhes oferecem ou impõem está sendo mostrada pela etnologia atual, são relevantes também na adaptação do próprio regime de subjetivação peculiar do ocidente, isto é, a constituição do indivíduo e suas ocasiões por excelência, a narração autobiográfica.

\section{Notas}

${ }^{1}$ Tratava-se da pesquisa para a minha tese de doutorado, defendida na USP em 1995, e publicada como livro pela Editora da Unesp em 2006. Os diálogos aqui referidos não foram gravados, nem, como o texto explica, tinham como objetivo uma autobiografia. Optei por isso pelo estilo indireto e evito identificar o autor pelo seu nome. ${ }^{2}$ Cf. Amich (1988), especialmente nas páginas 200-205 e 250, que tratam do caso de Ana Rosa, uma moça Setebo que assumiu um papel de primeira magnitude na 
política indígena da missão.

${ }^{3}$ Cf também Carneiro da Cunha (1998) sobre o xamã como tradutor cultural.

${ }^{4}$ Sobre esse mesmo recurso retórico cf. ainda Graham (2002, p.214) a respeito sobre os discursos da ativista Wayuu Noeli Pocaterra e o líder Xavante Warodi.

${ }^{5}$ O projeto de pesquisa "Transformações Indígenas: os regimes de subjetivação ameríndios à prova da história" (VVAA 2003) foi financiado, entre 2004 e 2007, pelo CNPq. Sob a coordenação geral de Eduardo Viveiros de Castro, foi realizado nos PPGAS do Museu Nacional-UFRJ e da UFSC.

${ }^{6}$ Entrevista realizada em 2004.

${ }^{7}$ Cf. Calavia Sáez (2004b) para um panorama mais geral da atual situação Guarani.

${ }^{8}$ Os Tuyuka são parte do conjunto Tukano, no noroeste da Amazônia. Desde 1914 até agora, os missionários salesianos têm atuado na região, e ficaram marcados na literatura antropológica pela sua política educacional e sua forte oposição aos rituais indígenas. Do Concílio Vaticano II em diante (embora com um certo atraso), essa atitude tem mudado de modo um tanto abrupto para uma revalorização retrospectiva do complexo cultural de Jurupari, devidamente domesticado em forma de "tradições culturais". Nessa nova situação também se situa a promoção do sacerdócio indígena: dois sacerdotes nativos foram ordenados, um Uanano e um Tuyuka (Cabalzar Filho, 1999).

${ }^{9}$ Agradeço a Nádia Heusi, da comissão editorial da revista Tellus, a possibilidade de consultar o texto antes de sua efetiva publicação.

\section{Referências}

ALBERT, Bruce. O ouro canibal e a queda do céu. Uma crítica xamânica da economia política da natureza. In: ALBERT, Bruce; RAMOS, Alcida R. Pacificando o branco. Cosmologias do contato no Norte-Amazônico. São Paulo: Edunesp, 2002.

AMICH, José. Historia de las misiones del convento de Santa Rosa de Ocopa. Iquitos: CETA-IIAP, 1988.

BASSO, Ellen The Last Cannibals. Austin: University of Texas Press, 1995.

BRUMBLE III, H. David. American Indian Autobiography. Berkeley: University of California Press, 1990.

BUCHILLET, Dominique. Nobody is there to hear. Desana Therapeutic Incantations. In: LANGDON, Esther J. (ed). Portals of Power. Shamanism in South America. Albuquerque: University of New Mexico Press, 1992, p. 211-230

CABALZAR FILHO, Aloísio. O templo profanado: missionários salesianos e a transformação da maloca tuyuka. In: WRIGTH, Robin M. (ed) .Transformando os deuses: Os múltiplos sentidos da conversão entre os povos indígenas no Brasil. Campinas: Editora da UNICAMP, 1999, p. 363-424

CALAVIA SÁEZ, Oscar. Extranjeros sin fronteras. Alteridad, nombre e historia entre los Yaminawa. Anuario Indiana. Berlin. v.19-20, p.73 - 88, 2003.

CALAVIA SÁEZ, Oscar. In search of ritual: Tradition, Outer World and bad manners in the Amazon. Journal of the Royal Anthropological Institute, v.1, n.10, p. 157-173, 2004a. 
CALAVIA SÁEZ, Oscar. La persistencia Guarani. Monográfico. Revista de Índias. Madrid: CSIC, v. XLIV, n.230, 2004 b.

CALAVIA SÁEZ, Oscar. O nome e o tempo dos Yaminawa. São Paulo: Editora da UNESP, 2006.

CARNEIRO DA CUNHA, Manuela. Pontos de vista sobre a floresta amazônica: xamanismo e tradução. Mana, Rio de Janeiro, n.4, v.1, p.7-22, 1998.

FAUSTO, Carlos. Inimigos fiéis. História, guerra e xamanismo na Amazônia. São Paulo: Editora da USP, 2001.

GRAHAM, Laura R. Performing Dreams. Discourses of Immortality among the Xavante of Central Brazil. Austin: University of Texas Press, 1995.

GRAHAM, Laura R. How should an Indian speak? Amazonian Indians and the symbolic politics of language in the Global Public Sphere. In: WARREN, Kay B.; JACKSON, Jean J. (eds). Indigenous movements, self-representation and the State in Latin America. Austin: University of Texas Press, 2002.

KOPENAWA, Davi: Sonhos das origens. In: RICARDO, Carlos Alberto (ed). Povos Indígenas do Brasil 1996-2000. São Paulo: Instituto Sócio-Ambiental, 2000, p.19-23 MENCHÚ, Rigoberta; BURGOS, Elizabeth. Me llamo Rigoberta Menchú, y así me nació la conciencia. México: Siglo XXI Editores, 1985.

OAKDALE, Suzanne. I foresee my life. The ritual performance of Autobiography in an Amazonian Community. Lincoln \& London/University of Nebraska Press, 2005. REZENDE, Justino Sarmento (in press). Aventuras de um Índio.

STOLL, David. Menchu and the Story of All Poor Guatemalans. Boulder, Colorado: Westview Press, 1999.

V.V.A.A. Transformações Indígenas: Os regimes de subjetivação ameríndios à prova da história. Projeto NuTI-PRONEX, 2003.

Urban, Greg. The 'I' of Discourse in Shokleng. In: LEE, Benjamin; URBAN, Greg. (eds) Semiotics, Self, and Society. Berlin: Mouton de Gruyter, 1989, p. 27-51

URBAN, Greg. A discourse-centered approach to culture: native south american myths and rituals. Austin: University of Texas Press, 1991.

VIVEIROSDE CASTRO, Eduardo. Araweté: os deuses canibais. Rio de Janeiro: Zahar, 1996.

VIVEIROS DE CASTRO, Eduardo. Os pronomes cosmológicos e o perspectivismo ameríndio. Mana, Rio de Janeiro. v.2, n.2, p.115-144, 1996.

VIVEIROS DE CASTRO, Eduardo. Atualização e contra-efetuação do virtual: o processo do parentesco. In: Cosac \& Naify, 2002, p. 401-455

WARREN, Kay B.; Jackson Jean J. 2002 Introduction: Studying indigenous activism in Latin America. In: WARREN, Kay B.; JACKSON, Jean J. (eds). Indigenous movements, self-representation and the State in Latin America. Austin: University of Texas Press, 2002.

Recebido em 10 de janeiro de 2007.

Aprovado para publicação em 02 de fevereiro de 2007. 